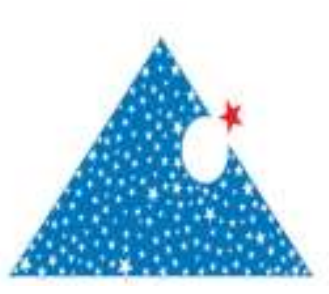

\title{
Microstructural Characterization and Corrosion-Resistance of Borided Rebar
}

\author{
Tayfun UYGUNOĞLU ${ }^{\mathrm{a}}$, Ibrahim GUNES ${ }^{\mathrm{b} *}$, Atila Gürhan ÇELIK ${ }^{\mathrm{c}}$, Emriye ÇINAR $^{\mathrm{d}}$ \\ ${ }^{a}$ Afyon Kocatepe University, Engineering Faculty, Civil Engineering Department, Afyonkarahisar, Turkey \\ ${ }^{\mathrm{b}, \mathrm{c}}$ Giresun University, Engineering Faculty, Civil Engineering Department, Giresun, Turkey \\ ${ }^{\mathrm{d}}$ Osmaniye Korkut Ata University, Engineering Faculty, Civil Engineering Department, Osmaniye, Turkey \\ ibrahim.gunes@giresun.edu.tr
}

\begin{abstract}
Received/Geliş: 06.03.2021
Accepted/Kabul: 05.07.2021

Abstract: The serviceability and ultimate strength of concrete elements within reinforced structures are affected negatively due to corrosion of steel bars. In the present paper, investigations were carried out to study the corrosion behavior of protected low carbon ribbed reinforcing steel with boron in concrete. The ribbed steel bars were in size of Ø12 and Ø14, and they were coated with boron. The coating process was carried out at 800,900 and $1000 \mathrm{oC}$ for $2 \mathrm{~h}$ and $4 \mathrm{~h}$, respectively. Depending on the boriding parameter the boride layer thickness on the surface of borided rebars ranged from $32.58 \mu \mathrm{m}$ and $213.74 \mu \mathrm{m}$. After boriding, the rebars were embedded into the concrete and exposed to rapid corrosion test. The results show that the corrosion rate and cross section loss of protected steel bars decreases when compared to unprotected rebars. Corrosion beginning time of borided rebars delayed about 2 times when compared to plain rebar. Boride layers reduced the corrosion rate of the reinforcements by 2.39 to 10.65 times and the section losses of the reinforcements by 2.54 to 4.72 times depending on the boriding temperature and duration.
\end{abstract}

Keywords: Rebar; borlama, corrosion; protection.

\section{Borlanmış Donatının Mikroyapısal Karakterizasyonu ve Korozyon Direnci}

Öz: Çelik çubukların korozyona uğraması nedeniyle betonarme yapılarda hizmet verilebilirliği ve nihai dayanımı olumsuz etkilenmektedir. Bu çalışmada borlanmış düşük karbonlu inşaat çeliğinin mikroyapı ve korozyon davranışları incelenmiştir. Çalışmada $\varnothing 12$ ve $\varnothing 14$ ebatlarında nervürlü çelik çubuklar kullanılmıştır. Çelik donatıların borlama işlemi sırasıyla 800,900 ve $1000{ }^{\circ} \mathrm{C}$ 'de 2 ve 4 saat süresince gerçekleştirilmiştir. Borlama parametresine bağlı olarak, borlanmış donatıların yüzeyindeki borür tabakası kalınlığı $32.58 \mu \mathrm{m}$ ile $213.74 \mu \mathrm{m}$ arasında değişmektedir. Borlama işleminden sonra, donatılar betona gömülüp hızlı korozyon testine tabi tutulmuştur. Borlanmış çelik çubukların kesit kayıplarının ve korozyon hızlarının borlanmamış çeliğe göre oldukça düşük çıkmıştır. Borlanmış inşaat demirinin korozyon başlama zamanı, borlanmamış inşaat demiri ile karşılaştırıldığında yaklaşık 2 kat gecikmiştir. Borür tabakaları, borlama sıcaklığına ve süresine bağlı olarak donatıların korozyon oranını 2,39 ila 10,65 kat, donatıların kesit kayıplarını ise 2,54 ila 4,72 kat azaltmıştır.

Anahtar Kelimeler: İnşaat demiri; borlama; korozyon; koruma.

\section{Introduction}

Durability in concrete materials is defined as the ability or resistance of concrete in environments exposed to abrasion, weather conditions and chemical attacks while maintaining material performance and service life in any environment [1]. Reinforced concrete is one of the most commonly used construction materials. During their service, reinforced concrete structures are

Uygunoğlu T., Gunes I., Çelik A.G., Çınar E.,." Borlanmış Donatının Mikroyapısal Karakterizasyonu ve Korozyon Direnci, El-Cezerî Fen ve Mühendislik Dergisi 2021, 8(3); 1135-1148. 
subjected to multiple physical and chemical degradation factors. Reinforcements in all structures provide structural security. However, corrosion of steel bars embedded in concrete is one of the main causes affecting the long-term performance of reinforced concrete structures. As a result of the penetration of substances into reinforced concrete structures, they cause deterioration in concrete and deterioration of reinforcements [2,3]. Steel embedded in quality concrete is protected by the high alkalinity of the concrete. The presence of oxygen passivates the steel. Due to the loss of alkalinity, the carbonization of the concrete and the penetration of chloride, it can destroy the passive film on the steel and the corrosion process starts quickly. Corrosion-related maintenance and repairs for reinforced structure cost over $\$ 100$ billion per annum in the world [4]. When the steel reinforcement in the reinforced concrete structure is corroded, it causes section loss and its adherence to the concrete decreases. Therefore, corrosion directly affects the strength of the reinforced concrete structural member [5]. Corrosion products formed as a result of the corrosion event have a higher volume than metal. Thus, in some parts of the section, the section decreases, whereas in some parts, the section increases. These irregularities occurring in the section cause the concrete to crack. The introduction of harmful substances into the cracking concrete is easier and corrosion occurs faster. The durability of the reinforced concrete structural element largely depends on the steel reinforcement used [6-9]. Many studies on the enhancing of mechanical properties of rebars have been carried out. Ding and Poursaee (2017) examined the passivation and corrosion performance of sandblasted steel embedded in concrete. They applied at different blasting times (5, 10, 15 minutes) and added solutions containing 3\% chlorine ion after 14 days. As a result, they observed a significant increase in corrosion resistance in sandblasted reinforcements compared to non-sandblasted steel reinforcements [10]. They also found that during blasting times outside of 15 minutes, the thin passive layer and corrosion density increased [11]. This improvement was proportional to the increase in the sandblasting time. Song et al. (2014), in their study, investigated the effect of reinforcement on corrosion resistance by increasing the surface area of steel reinforcement. They created a $25 \mu \mathrm{m}$ thickness NC layer with the help of a wire brush. The NC layer formed with an average grain size of $50 \mu \mathrm{m}$ increases passivation. High-energy crystal defects of nano grains cause the passive film of the SNC reinforcement bar to passively pass and increase its stability [12]. In the light of the literature review, it is seen that many engineering materials and applications are available for the improvement of surface properties [13]. Many methods were tried in order to counteract the early steel rebar corrosion in concrete like providing epoxies on the surface of the bar and various other methods but the provision of surface protection system was not economical and, in some cases, have to be repeated over the period of the enhanced life. For this reason, it has been searched for various solutions and alternatives to prevent corrosion damage [1416]. One of them is boriding of steel materials. Boriding is a thermo-mechanical surface hardening process and forms a borides layer on the reinforcement surface [17]. The materials applied with the borides layer can be made stronger against corrosion and wear [18]. Generally, thermal diffusion processes take place at $700-100^{\circ} \mathrm{C}$ process temperatures to form a borides layer on metal [19]. In this study, the resistances of boron coated rebars against corrosion in concrete was investigated by subjecting two different diameter rebars to boriding process at different temperatures and times.

\section{Experimental Program}

\subsection{Materials}

The reinforcements used in reinforced concrete structures are generally produced from mild steel with low carbon content. With too little carbon content $(>0.2 \%)$ to thoroughly harden, it is weldable, which expands the possible applications. The experiments of this study were performed on ST-IIIa (S 420) ribbed reinforcement steel rebar specimens in size of $\varnothing 12$ and $\varnothing 14$. The characteristic properties of rebar were presented in Table 1. 
Table 1. Characteristic properties of steel rebars

\begin{tabular}{lcc}
\hline \multicolumn{1}{c}{ Properties } & Steel rebar, Ø12 & Steel rebar, Ø14 \\
\hline Area $\left(\mathrm{mm}^{2}\right)$ & 113.04 & 153.86 \\
Initial length $(\mathrm{mm})$ & 120 & 140 \\
Last length $(\mathrm{mm})$ & 150.72 & 172.06 \\
Yield force (N) & 49967 & 68775 \\
Tensile fore (N) & 67711 & 86269 \\
Yield stress (MPa) & 442 & 447 \\
Tensile stress (MPa) & 599 & 560.7 \\
Elongation, \% & 25.6 & 22.9 \\
\hline
\end{tabular}

\subsection{Coating of Rebars}

In the study, boriding layer was performed as coating on the steel rebar surface. Boriding heat treatment was carried out by using a solid boriding method with commercial Ekabor-II powders. Samples to be boiled in a steel container were placed with the powder mixture. The rebars are placed in the boron box with $1,5 \mathrm{~cm}$ distance between them. After commercial ekabor 2 boron powder was filled into it, the lid of the box was closed and plastered with fireclay mud to prevent air from entering. Boriding heat treatment was performed in an electrical resistance furnace under atmospheric pressure at $800^{\circ} \mathrm{C}, 900^{\circ} \mathrm{C}$ and $1000^{\circ} \mathrm{C}$ for $2 \mathrm{~h}$ and $4 \mathrm{~h}$ followed by cooling in air (Fig. 1). The microstructures of polished and etched cross-sections of the specimens were observed under a Nikon MA100 optical microscope.

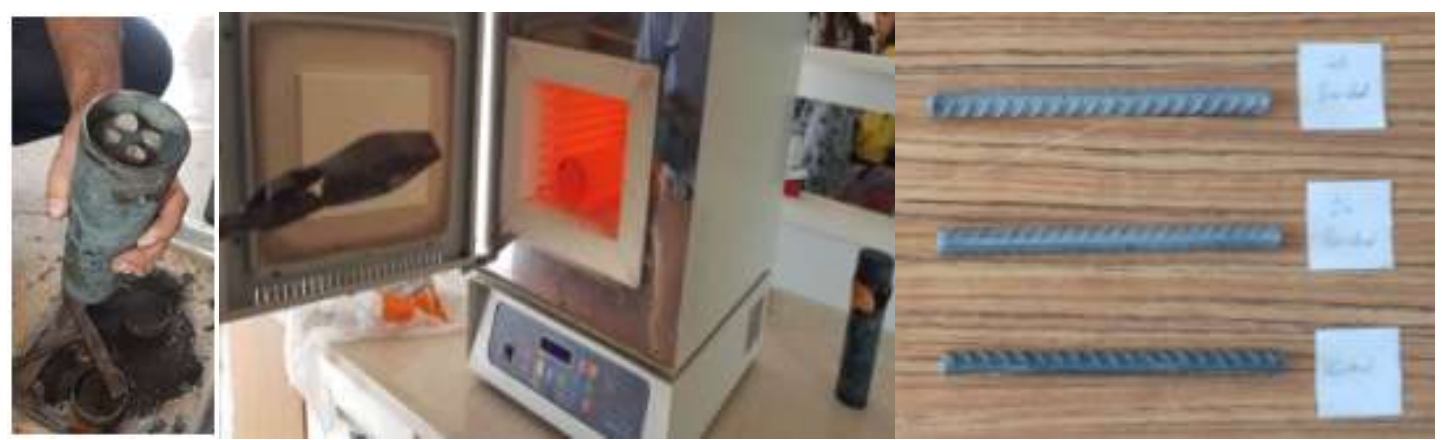

Figure 1. Coating process of rebar by boriding

\subsection{Sample Production and Corrosion Test}

Two different aggregate sizes, $0 / 6 \mathrm{~mm}$ and $6 / 12 \mathrm{~mm}$ were used in the production of concretes. The specific gravity of aggregates is 2.63 for $0 / 6 \mathrm{~mm}$, and 2.69 for $6 / 12 \mathrm{~mm}$. They were used in ratio of $50 \%-50 \%$. In all mixtures, $350 \mathrm{~kg}$ of cement is used as binder. The workability values of the produced concrete have been tried to be kept constant, and the slump value has been decided to be around $20 \mathrm{~cm}$. Concrete specimens were produced by using the cylindrical mould of size ø100x200 $\mathrm{mm}$. The reinforcement rebar was held in position and concrete was poured into the mold. After 24 $\mathrm{h}$, the reinforced concrete specimens were demolded and cured in a water pool until the time of test was reached. The specimen was allowed to cure for 28 days. The specimens were cast in constant strength classes such as $\mathrm{C} 25$ for corrosion test.

The test setup consists of a constant DC supply providing constant voltage of $50 \mathrm{~V}$. The test was carried out in a $4 \% \mathrm{NaCl}$ solution with an embedded reinforcement bar as a working electrode and a copper bar as a counter electrode. The variable parameter current was recorded at every 20 min 
interval in constant voltage study. The set up was kept for until cracking of concrete samples without disrupting the power supply. After cracking of concrete, the solution turned to reddish brown in color due to the formation of rust. Then the specimens were removed from the set up, dried in air, visually inspected and carefully split open to access the corroded steel bar. Simultaneously, the temperature of the solution was recorded together with the voltage value. The amount of corrosion in terms of mass loss of the reinforcing bar due to corrosion can be determined by the following equation (1):

$$
\% \mathrm{~W}_{\mathrm{c}}=\left[\left(\mathrm{W}_{0}-\mathrm{W}\right) / \mathrm{W}_{0}\right] \times 100
$$

Where, $\mathrm{W}_{\mathrm{c}}$ is weight loss after corrosion test; $\mathrm{W}_{\mathrm{o}}$ is the initial weight of rebar and $\mathrm{W}$ is weight of rebar after corrosion test.

\section{Results and Discussions}

The thickness of the boride layer formed on the rebar samples is shown in Figure 2 and Figure 3. It has been observed that the boride layer thickness increases with the increase in the boriding temperature and time. Depending on the boriding parameter (temperature, time and rebar diameter), the boride layer thickness on the surface of borided rebars ranged from $32.58 \mu \mathrm{m}$ and $213.74 \mu \mathrm{m}$. Since the boriding process is a thermochemical process, temperature and time provide diffusion of more boron atoms in rebar and cause the boride layers to grow [20-22]. Variation of the thickness of the boriding layer with time at different boriding temperatures in Figure 4 is given. The highest boriding layer $(213.74 \mu \mathrm{m})$ was obtained in samples borided at $1000^{\circ} \mathrm{C}$ for 4 hours. The lowest boride layer thickness $(32.58 \mu \mathrm{m})$ was obtained in samples borided at $800^{\circ} \mathrm{C}$ for 2 hours.
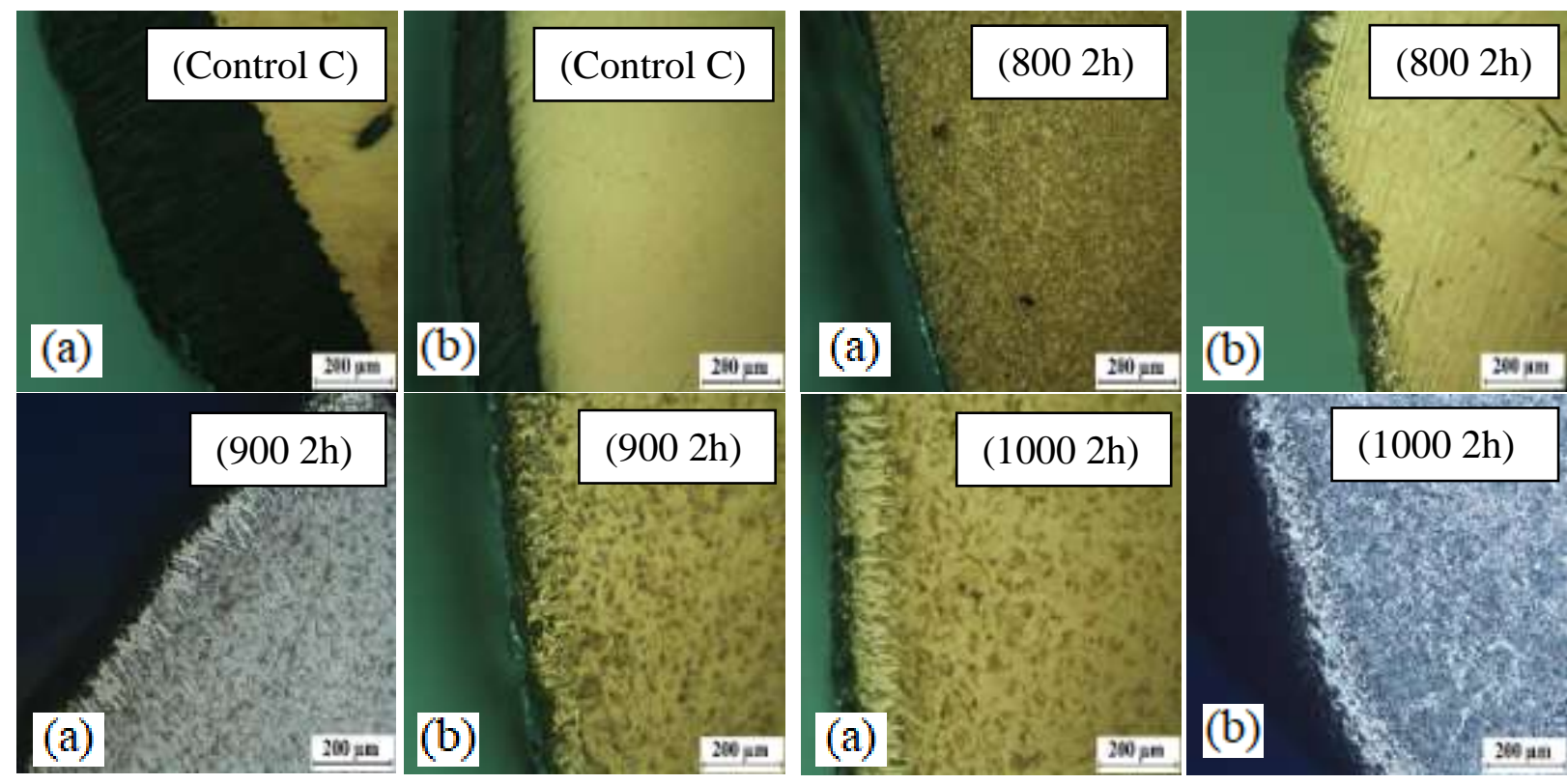

Figure 2. Microscope image of $2 \mathrm{~h}$ borided rebar section before (a) and after corrosion (b) depending on temperature for $Ø 14$

Rapid corrosion tests are widely used by electrical stress method. Electrochemical cells arise from electrical differential differences on steel reinforced steel reinforcement. In the steel one part becomes anode and other part becomes cathode. They connected by electrolyte in the form of pore water in the hardened cement paste [23]. It is well known that steel rebars exposed to corrosion when ambient conditions are appropriate. Figure 5 and Figure 6 shows the current versus time 
values during the accelerated corrosion test (Ø12 reinforcement in Fig. 5, Ø14 reinforcement in Fig. 6 ). When the voltage is applied firstly to the samples, the current values begin to decrease. After a while the current values reach the minimum value and become stable. It is understood that the corrosion process started when the current started to increase again. The current values start to decrease again after taking the maximum value.
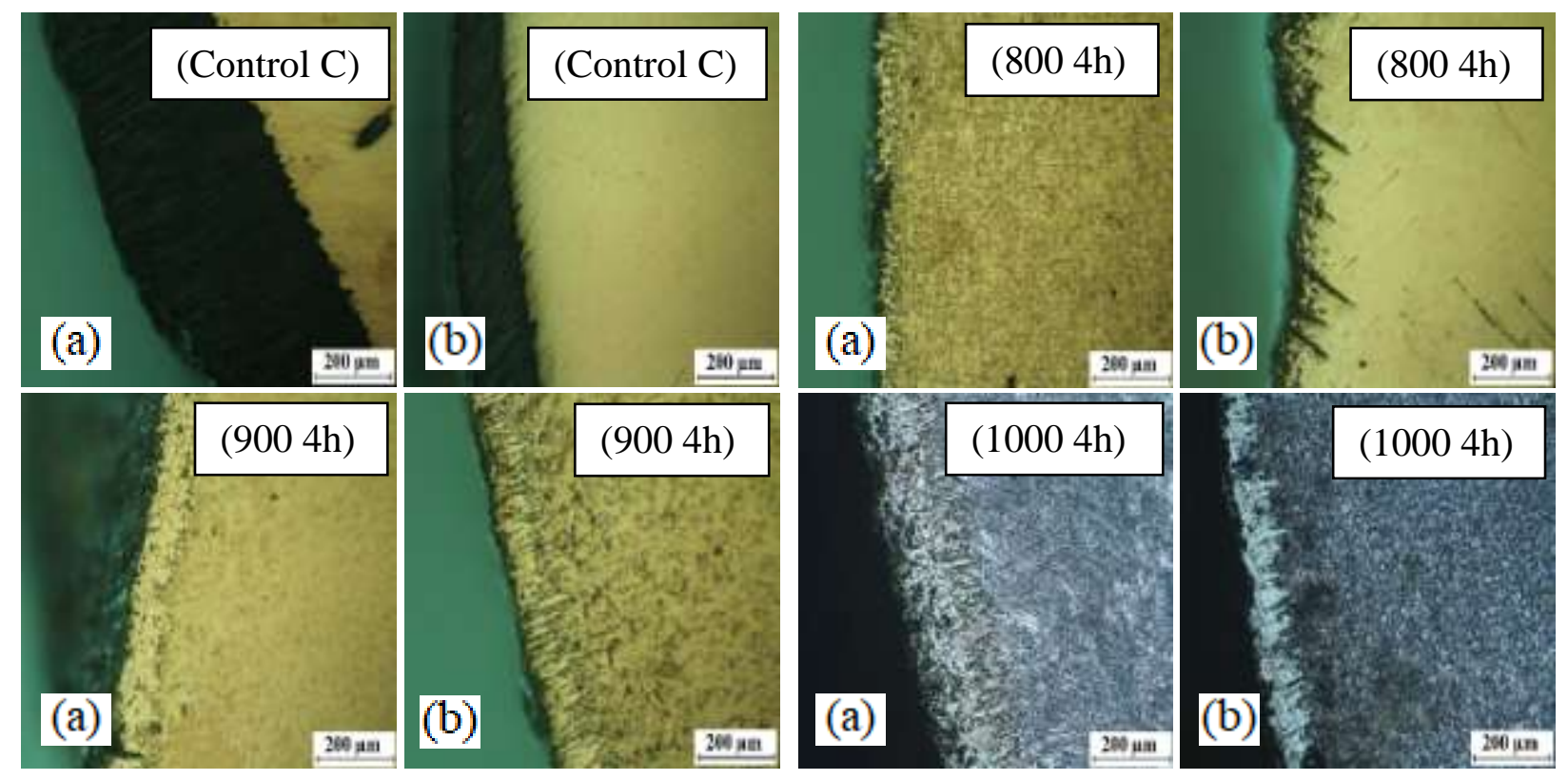

Figure 3. Microscope image of $4 \mathrm{~h}$ borided rebar section before (a) and after corrosion (b) depending on temperature for $Ø 14$

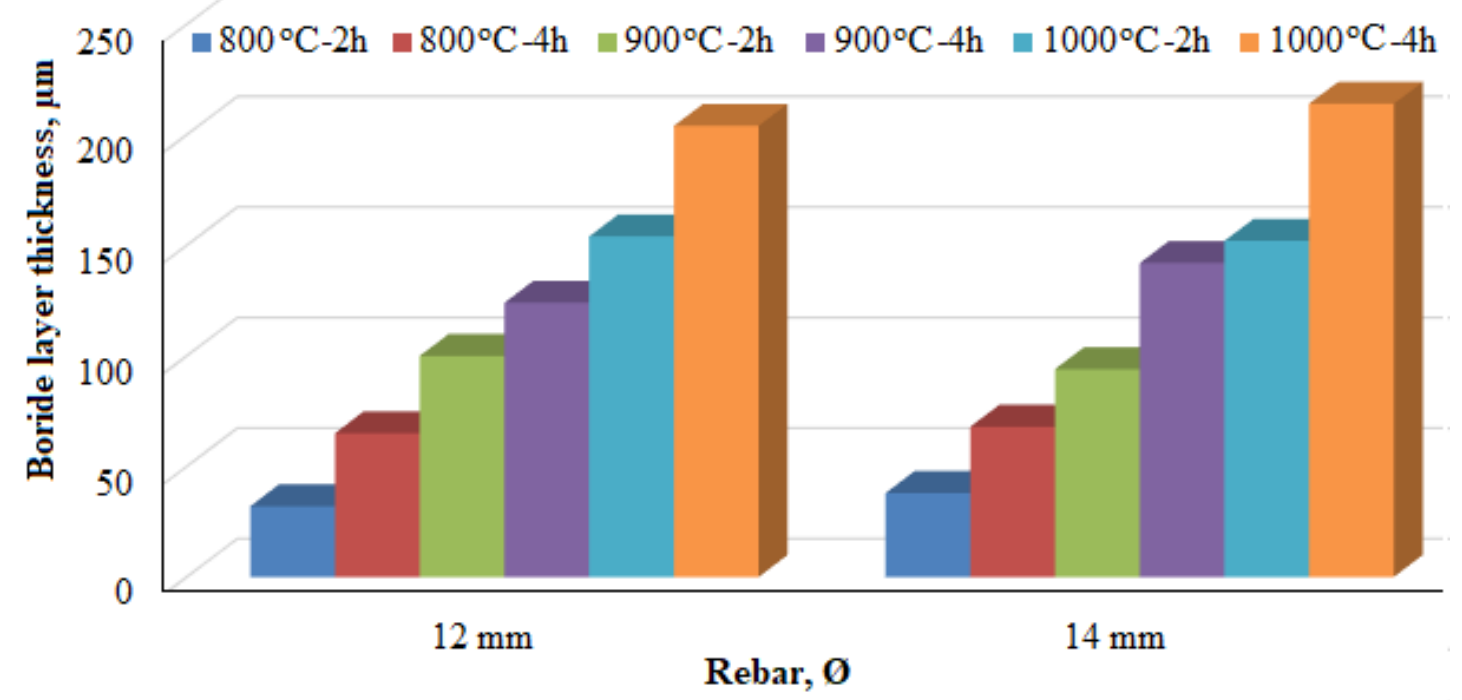

Figure 4. Variation of thickness of boriding layer with time at different boriding temperatures

Here, corrosion time for the started to increase is an indicator of cracking of concrete samples. It can be clearly seen that borided reinforced concrete sample has lower current values than control sample. However, corrosion starting time is also longer for borided reinforced sample when compared to control sample. This is because of the boride layers mainly consist of intermetallic phases $\left(\mathrm{FeB}, \mathrm{Fe}_{2} \mathrm{~B}\right.$ and $\left.\mathrm{CrB}\right)$ as a result of diffusion of boron atoms from the boriding compound to the metallic lattice with respect to the holding time. Thus, electron flowing from metal to solution carried out very slowly, and corrosion time increases by boriding of rebars. 

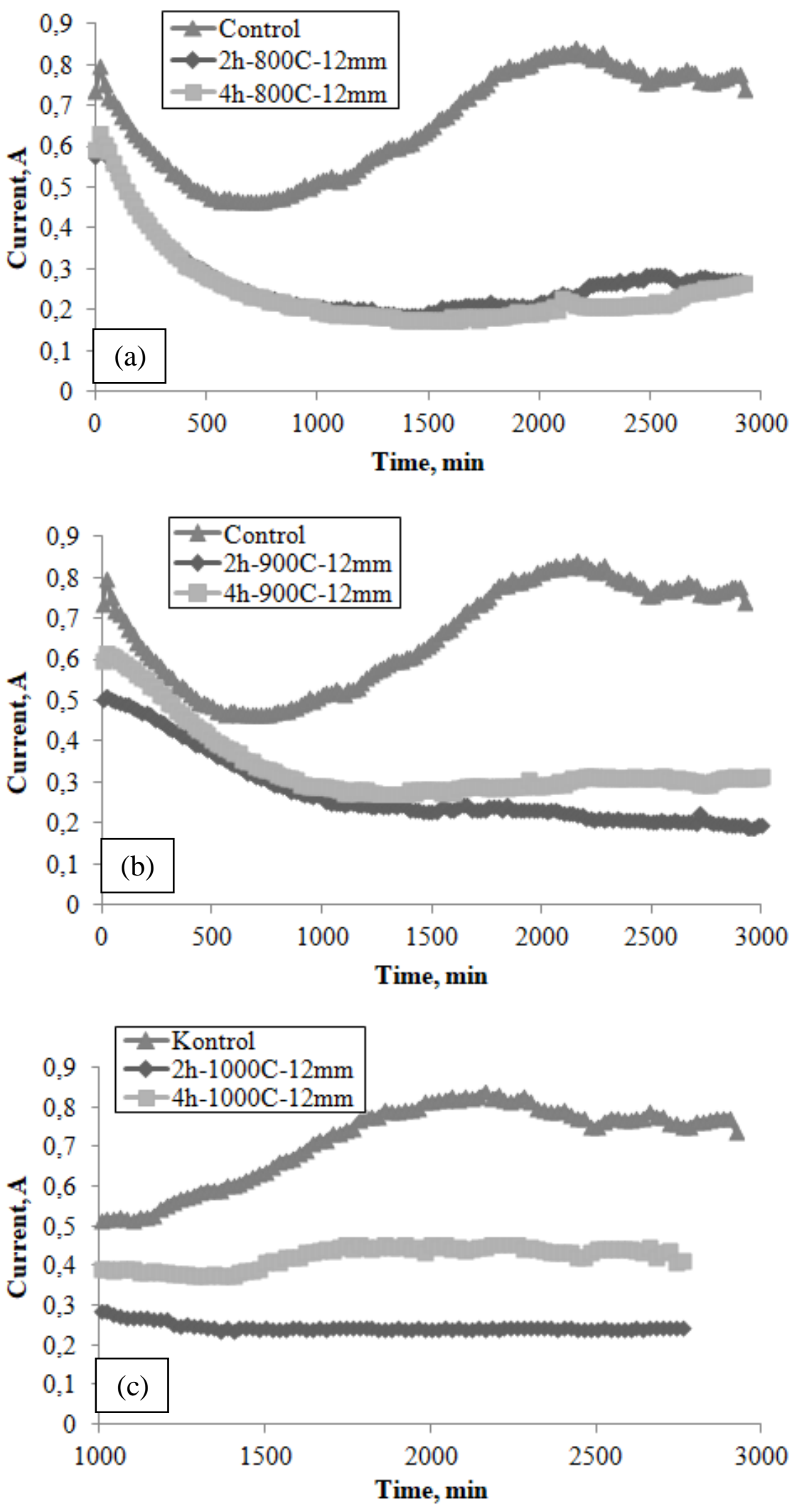

Figure 5. Comparison of current values for $\emptyset 12$ borided reinforcement during corrosion test (a : $800{ }^{\circ} \mathrm{C}$; b: $900{ }^{\circ} \mathrm{C}$; c. $1000{ }^{\circ} \mathrm{C}$ )

Corrosion starting time plays an important role in the service life and rehabilitation of reinforced concrete structures [24-26]. In order to see the effect of reinforcement surface boriding on corrosion 
initiation times, the corrosion starting time was determined on Figure 7. It is clearly seen that boriding on the surface of the reinforcement is very effective.
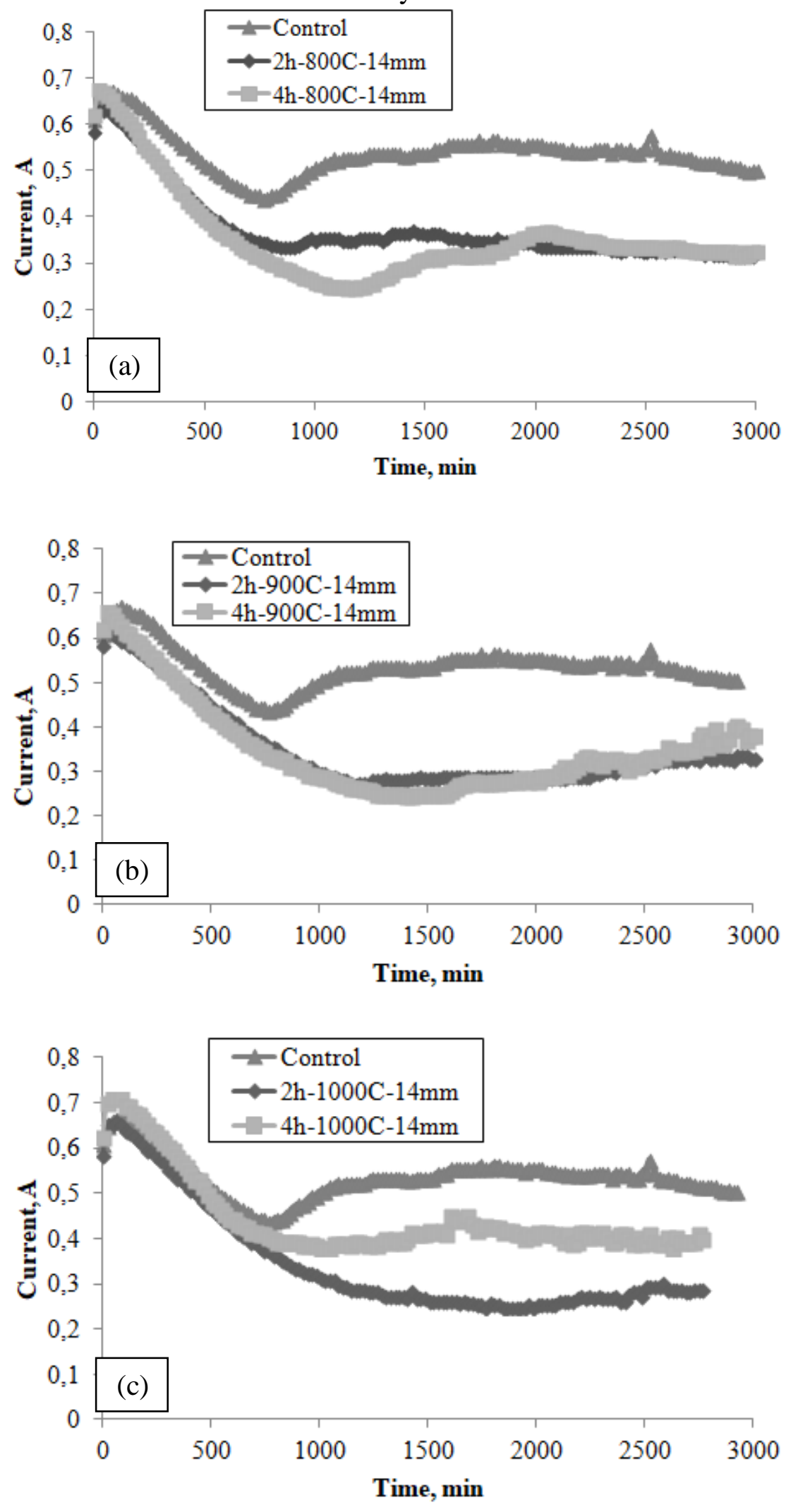

Figure 6. Comparison of current values for $\emptyset 14$ borided reinforcement during corrosion test (a: $\left.800{ }^{\circ} \mathrm{C} ; \mathrm{b}: 900{ }^{\circ} \mathrm{C} ; \mathrm{c} .1000{ }^{\circ} \mathrm{C}\right)$ 
For these two types of reinforced concretes, corrosion time of borided rebars about 2 times higher than non-coated steel rebars. In other words, if the traditional reinforced structures with steel rebar exposed to corrosion after 10 years, same structures will be corroded after 20 years when borided rebar are used.
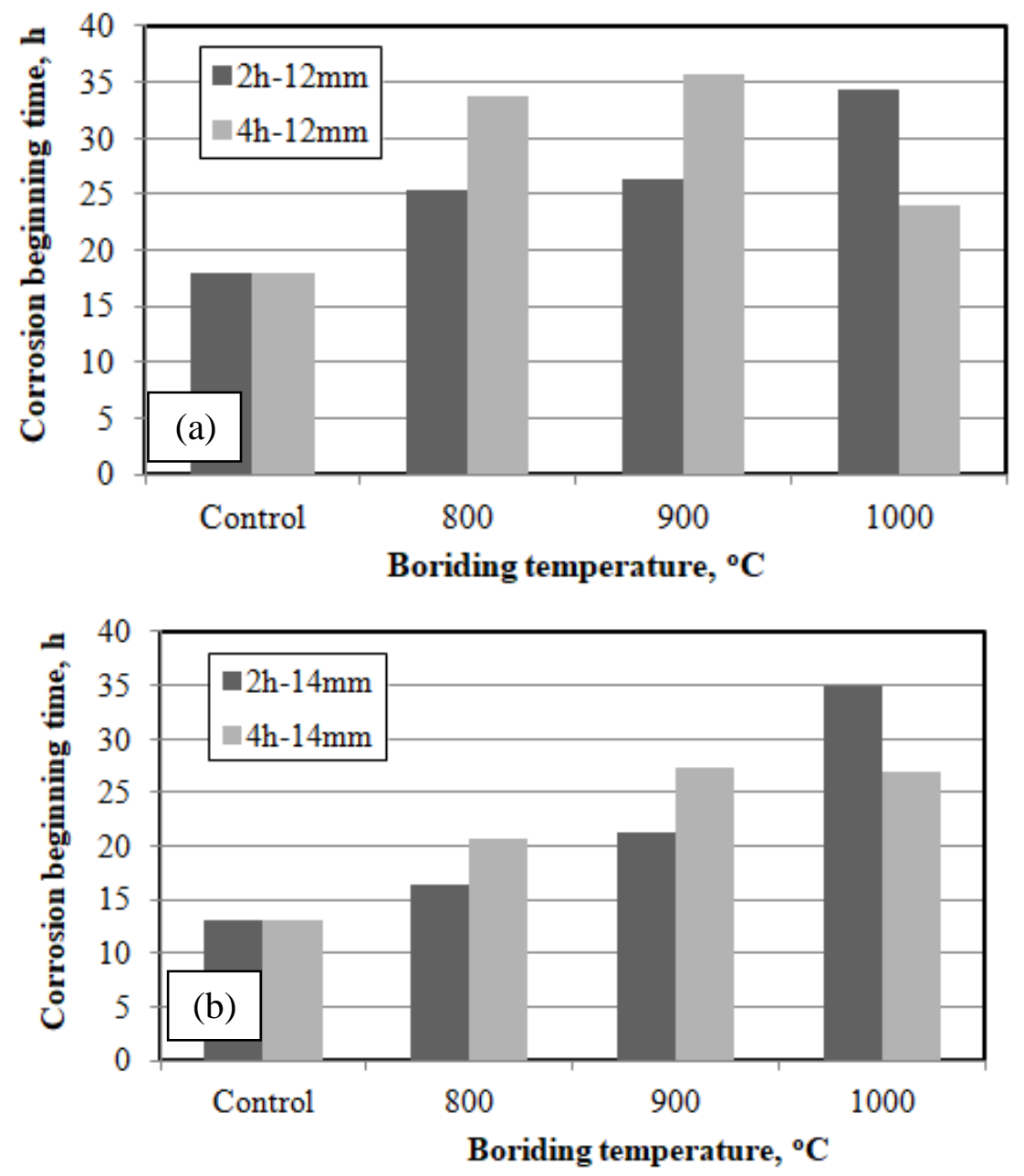

Figure 7. Corrosion initial time of control and borided reinforced concrete (a: Ø12; b: Ø14)

After the corrosion test for the same period in Figure 8 and Figure 9, concrete samples were divided and internal color change was examined (Ø12 reinforcement in Fig. 8, Ø14 reinforcement in Fig. 9).

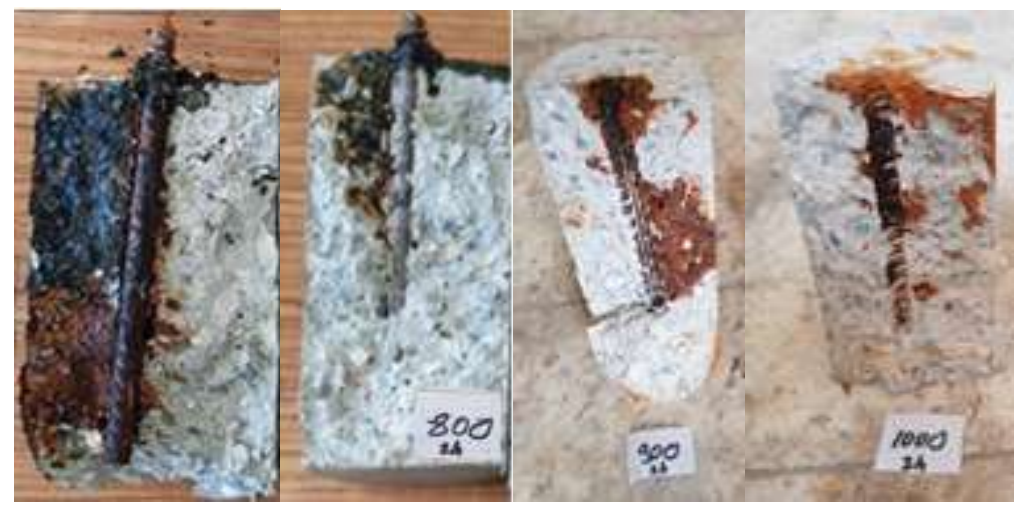

Figure 8. Inner view of corroded $\emptyset 12$ reinforced samples depending on boriding temperature 


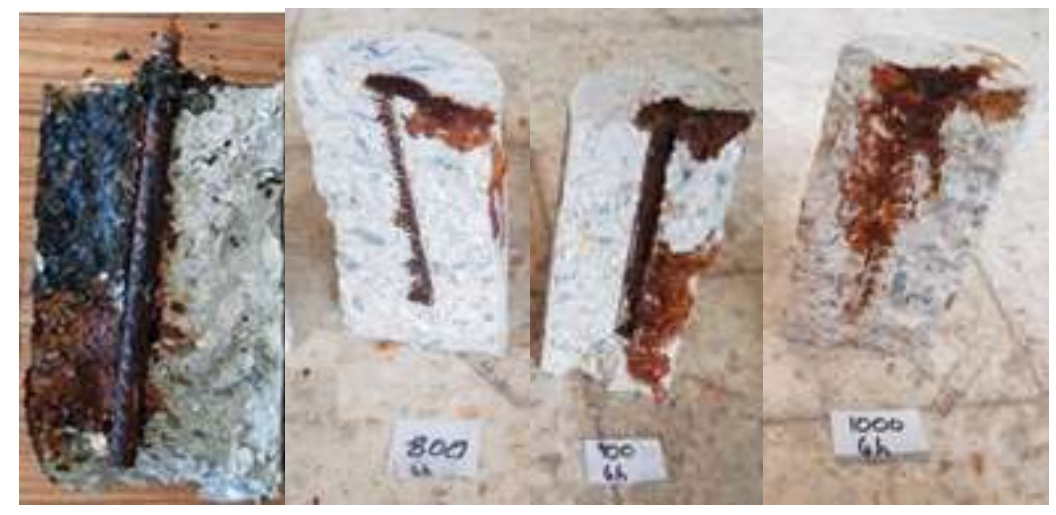

Figure 9. Inner view of corroded $\emptyset 14$ reinforced samples depending on boriding temperature

It is clearly seen that reinforcement with borided steel rebar has lower corrosion rust in the concrete than produced with steel rebar. About all the concrete side along the steel is rusty area. On the other hand, in the concretes produced with borided rebar, the rusty area is yet to reach the outer surface of the concrete. Rebars were removed from splitted concretes and weight loss were determined after cleaning. Figure 10 shows weight loss of rebars after corrosion experiment. The loss of weight of steel rebar in concrete is determined as $12 \%$. By coating the rebar surface with boriding, the loss of weight is estimated as 3.9\%. Figure 10 shows weight loss of control and borided reinforced rebar. It is seen in Figure 10a and 10b that the weight losses of the control samples with a diameter of 12 $\mathrm{mm}$ are higher than the weight losses of the boronized samples.

The boriding process caused reductions in the corrosion weight losses of steel reinforcements. The lowest weight loss was observed in the sample borided at $1000^{\circ} \mathrm{C}$ for 2 hours, while the highest weight loss was obtained in the control sample (Figure 10a). Boriding process has reduced the weight loss rate compared to the control sample by $265 \%$ at $800^{\circ} \mathrm{C}$ for 2 hours, $739 \%$ at $900^{\circ} \mathrm{C}$ for 2 hours, and $1088 \%$ for $1000^{\circ} \mathrm{C}$ hours for 2 hours. In the samples borided for 4 hours, $\%$ decreases in weight loss amounts are as follows; It decreased by $180 \%$ at $800^{\circ} \mathrm{C}, 653 \%$ at $900^{\circ} \mathrm{C}$ and $242 \%$ at $1000^{\circ} \mathrm{C}$. Boriding process reduced the weight losses compared to unborided samples at very high rates and increased the lifetime of the steel reinforcement in concrete. It is observed that the weight losses in $14 \mathrm{~mm}$ steel reinforcement are slightly higher than the $12 \mathrm{~mm}$ diameter reinforcement (Figure 10a and 10b). However, it has been determined that the weight loss values of the borided samples are quite low compared to the control sample. The reason for this is that due to the increasing reinforcement diameter, the surface area where the rebar contacts with the concrete increases. As the diameter of the steel reinforcement increases, the surface contact area with the concrete increases. This means more corrosion contact area. As a result, as the surface contact of the steel reinforcement increases, weight loss increases. The surface roughness values of steels increase with increasing temperature and time of boriding. Krelling et al. (2019) borided AISI 1020 steel. They determined that it increased the surface roughness value from $0.17 \pm 0.09$ before boriding up to $2.36 \pm 0.04 \mu \mathrm{m}$ [27]. Gunes (2013) has borided AISI 8620 steel in plasma environment with five different borax and $\mathrm{B}_{2} \mathrm{O}_{3}$ paste mixtures, and as a result, it has been determined that the surface roughness values of all samples have increased with the increase in boriding temperature and time [28]. Ergun et al. (2017) borided AISI 420 and AISI 5120 steels with Ekabor II boron powder at $950^{\circ} \mathrm{C}$ for 5 hours and subjected to corrosion test in $4 \% \mathrm{M} \mathrm{HCI}$. They found that borided steels increase corrosion resistance 8 times compared to unborided steels [29]. Erdogan et al. (2014) GS18NiMoCr36 (GS 18) and GS32NiCrMo6.4 (GS 32) borided the gear steels at $950^{\circ} \mathrm{C}$ for 2 and 6 hours and investigated the corrosion resistance in $6 \% \mathrm{M} \mathrm{HCI}$ acid. They observed that the boriding process improved the weak corrosion properties of the GS 18 and GS 32 gear steels by 4 to 6 times [30]. Gunes et al. (2014) Examined the corrosion behavior by subjecting 
both plasma nitriding and boriding. They obtained higher corrosion resistance of the boriding sample compared to both the unborided control sample and the plasma nitrided sample [31].
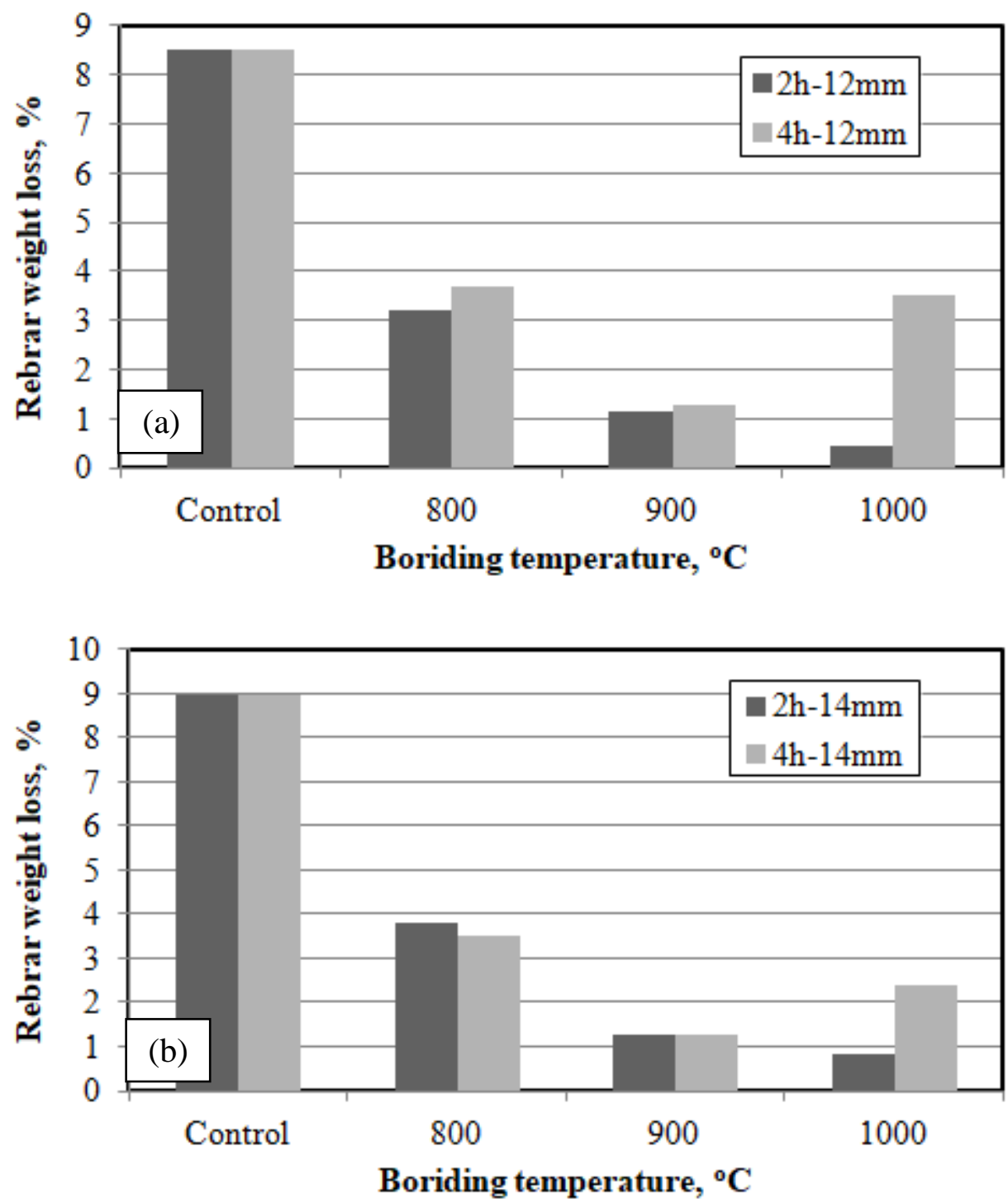

Figure 10. Weight loss of control and borided reinforced rebar (a: Ø12; b: Ø14)

Figures $11 \mathrm{a}$ and $11 \mathrm{~b}$ show the percent cross-sectional losses of $12 \mathrm{~mm}$ and $14 \mathrm{~mm}$ diameter rebar. As the boriding temperature increased, the cross-sectional losses decreased the rebar. There are micro cracks and scratches on steel reinforcements that will result from production. There are micro cracks and scratches caused by production on steel reinforcements. As the boriding temperature increases, the voids, pores and scratches on the steel reinforcement are filled with the boride layer and become more resistant to corrosion. In addition, as the boriding temperature increases, the boride layer thickness on the reinforcement increases. If the boriding temperatures and durations are increased more, the boride layers become larger and thicker, the surface contact area increases and the surface roughness values increase. Due to the high surface roughness values in the samples borided for 4 hours, it increases the corrosion a little. The higher the roughness value in the steels before boriding in steels, these rough places are filled with boride layers and the surface roughness levels decrease as a result of boriding. However, if the surface roughness value of steel samples before boriding is low, it increases the surface roughness value after boriding. Sahin (2009) borided AISI 1020, AISI 1040 and AISI 2714 steels at $900^{\circ} \mathrm{C}$ for 2 and 4 hours, and made a study on how the boriding process affects the surface roughness values of the steels [32]. In this study, it has been 
determined that the roughness values of the steels before the process are very important and the surface roughness of the boriding process decreases the roughness values, while the surface roughness value of the surface before the process increases the roughness value.
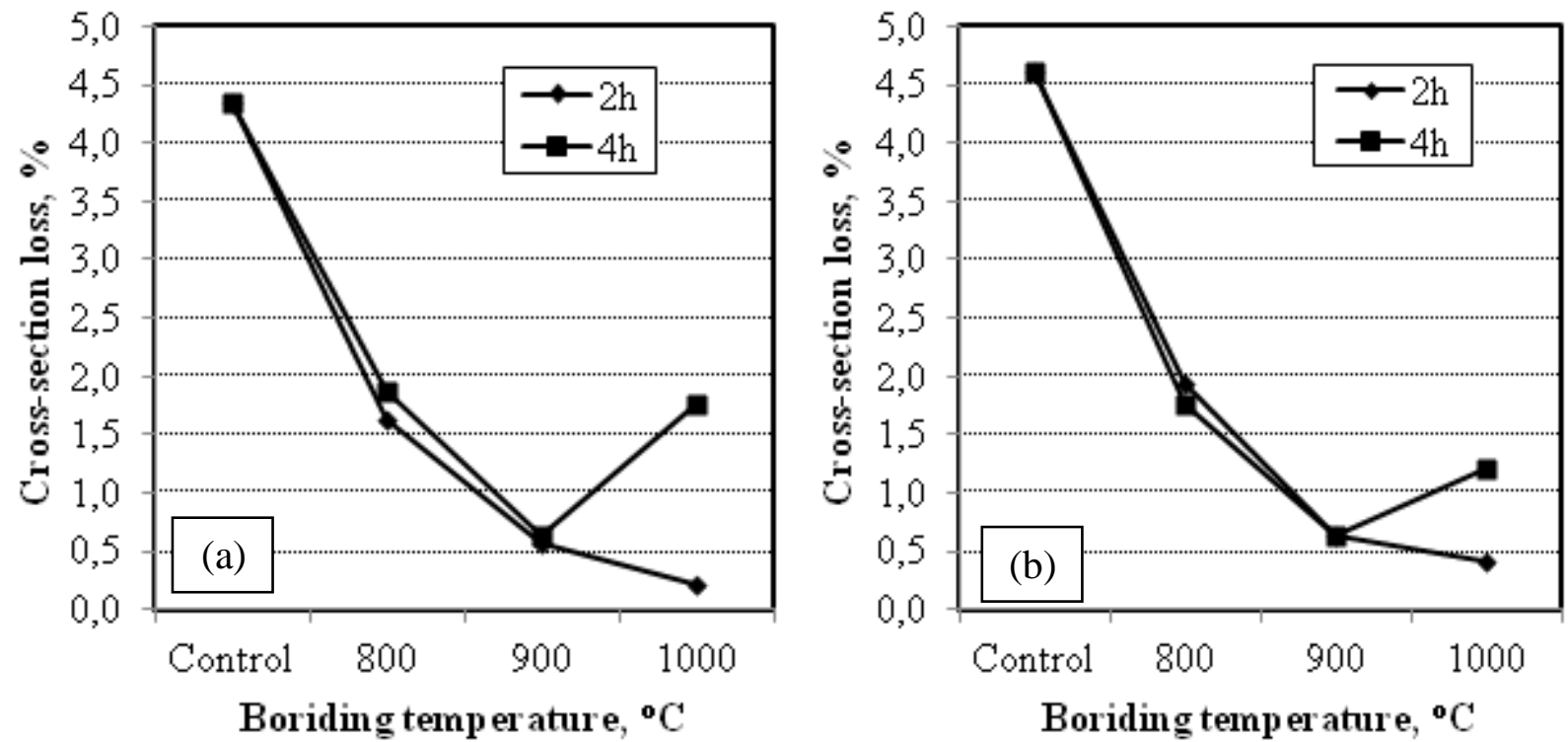

Figure 11. Cross-section loss of rebars in size of a: Ø12 and b: Ø14 versus boriding temperature

In Figure $12 \mathrm{a}$, the process of boriding at $800^{\circ} \mathrm{C}$ reduced the corrosion rate by 2.75 times in the 2hour borided sample and 2.34 times in the 4-hour borided sample. Boriding process at $900^{\circ} \mathrm{C}$ and $1000^{\circ} \mathrm{C}$ for 2 and $4 \mathrm{~h}$, respectively, according to the control rate of the corrosion rate of $900^{\circ} \mathrm{C}-2 \mathrm{~h}$; $6.47-900^{\circ} \mathrm{C}-4 \mathrm{~h} ; 6.12-1000^{\circ} \mathrm{C}-2 \mathrm{~h} ; 18.4-1000^{\circ} \mathrm{C}-4 \mathrm{~h}$; It decreased 2.4 times (Figure 12a). By reducing the corrosion rates of steel reinforcements within the concrete, it will enable the building of longer-lasting buildings. Similar results were obtained with the $14 \mathrm{~mm}$ steel reinforcement as for the $12 \mathrm{~mm}$ steel reinforcement (Figure 12b).
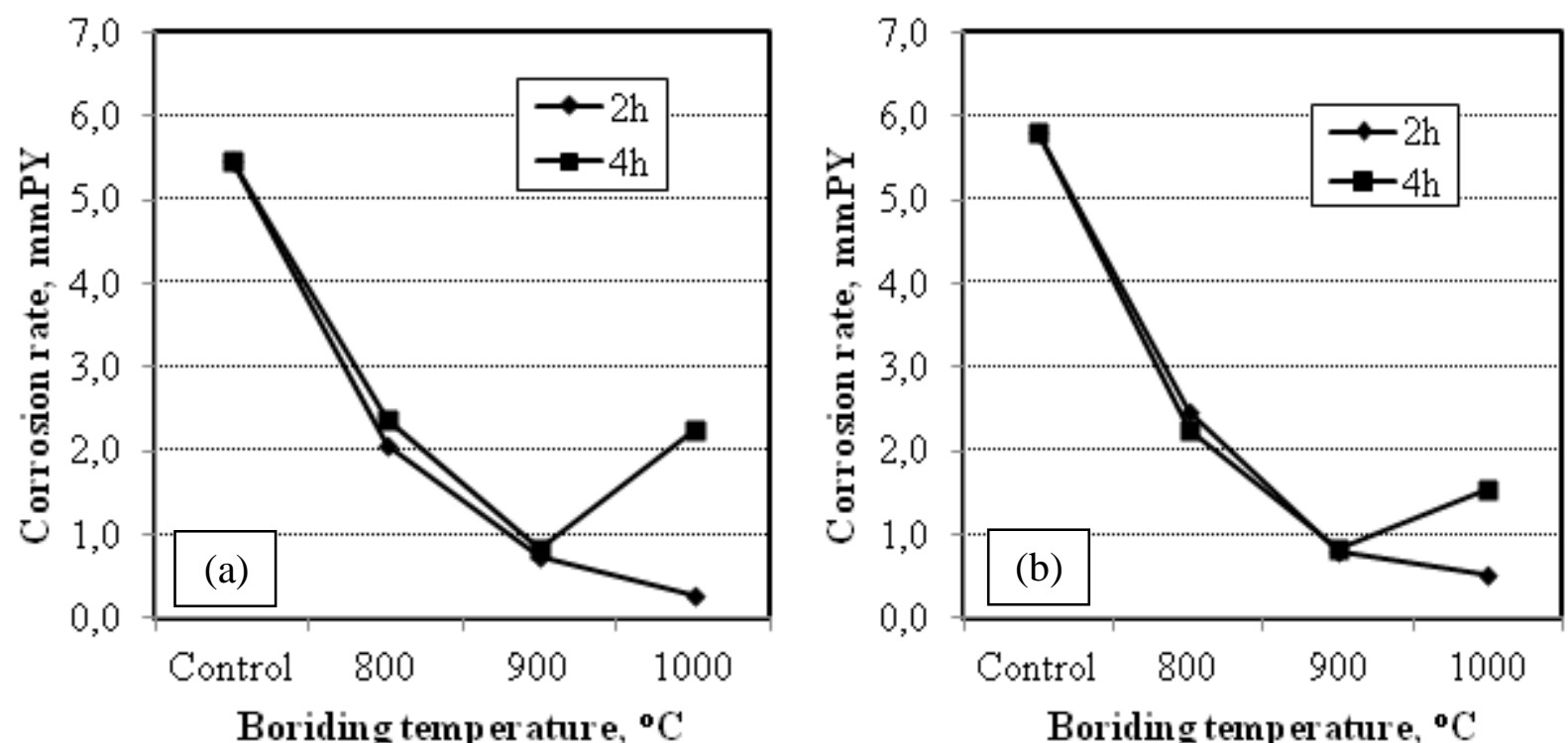

Figure 12. Cross-section loss of rebars in size of a: Ø12 and b: Ø14 versus boriding temperature 
The corrosion rates of the boriding process on steel reinforcements for 4 hours at $1000^{\circ} \mathrm{C}$ were slightly higher than the samples borided for 2 hours at $1000^{\circ} \mathrm{C}$. These results show us that the steel reinforcements, which are borided for more than 2 hours at $1000^{\circ} \mathrm{C}$, will not provide more corrosion resistance and this time should be accepted as the boundary boriding process time in boriding. Boriding of reinforcements $1000^{\circ} \mathrm{C}-4 \mathrm{~h}$ caused increased roughness values on the steel surface, increased surface contact area and increased the corrosion rate slightly. In addition, steels are not desired to be exposed to high temperatures and times for a very long time. Because this situation causes the growth of the grains in the steel and the decrease of their mechanical properties [33]. Therefore, they are required to be exposed to temperatures and times as low as possible in steels. In addition, the boride layer thicknesses to be obtained with the increase in the temperature and duration of the boriding increase more [34-37]. Thus, it closes micro cracks on rebar and reduces its corrosion rate.

\section{Conclusions}

In the study, investigations were carried out to study the corrosion behavior of protected low carbon ribbed reinforcing steel with boron in concrete. Following results have appeared:

- Reinforced concrete sample with borided steel rebar has lower current values than control sample. However, corrosion starting time is also longer for reinforced sample containing the borided rebar when compared to control sample.

- Electron flowing from metal to solution carried out very slowly, and corrosion time increases by boriding of rebars.

- Corrosion time of borided rebars about 2 times higher than non-coated steel rebars.

- Boride layers reduced the section losses of the reinforcements by 2.54 to 4.72 times.

- Reinforcement with borided steel rebar has lower corrosion rust in the concrete than produced with steel rebar.

- The loss of weight of steel rebar in concrete is determined as $12 \%$. By coating the rebar surface with boriding, the loss of weight is estimated as $3.9 \%$.

- As the boriding temperature increased, the cross-sectional losses decreased the rebar.

- As the boriding temperature increased, the voids, pores and scratches in the steel reinforcement were filled with the boride layer and became more resistant to corrosion.

- Boride layer thicknesses to be obtained with the increase of temperature and boriding time have increased even more. Thus, by closing the micro cracks on the rebar and reduced the corrosion rate.

- Boride layers reduced the corrosion rate of the reinforcements by 2.39 to 10.65 times depending on the boriding temperature and duration.

Consequently, service life of reinforced structures which are under corrosion risk can be increased two times by protecting the steel rebars by boriding. Boriding technology can be used the alternatively to other rebar surface coatings.

\section{Acknowledgement}

The authors would like to thank the editor and anonymous reviewers for their comments that help improve the quality of this work. Authors thank to Afyon Kocatepe University for supporting the study with 18.KARIYER.209 Scientific Research Project.

\section{Authors' Contributions}

TU came up with the idea of the study. TU and IG carried out the experimental studies together. AGC and EC contributed to the interpretation and English writing. All authors have read and approved the final version of the article. 


\section{Conflict of Interest}

The authors confirm that there is no conflict of interest to declare for this publication.

\section{References}

[1]. Dong, Z., Gang, W., Xu, Y. "Experimental study on the bond durability between steel-FRP composite bars (SFCBs) and sea sand concrete in ocean environment", Construction and Bulding Materials, 2016, 115: 277-284.

[2]. Du, F., Jin, Z., Xiong, C., Yu, Y., Fan, J. "Effects of Transverse Crack on Chloride Ions Diffusion and Steel Bars Corrosion Behavior in Concrete under Electric Acceleration", Materials, 2019,12(15): 2481-2500.

[3]. Xi, X., Yang, S. "Time to surface cracking and crack width of reinforced concrete structures under corrosion of multiple rebars", Construction and Bulding Materials, 2017, 155: 114-125.

[4]. Chen, Z.J. "Effect of reinforcement corrosion on the serviceability of reinforced concrete structures", MSc thesis, Department of Civil Engineering, University of Dundee, Dundee, Scotland. 2004.

[5]. Jaffer, S.J., Hansson, C.M. "Chloride-induced corrosion products of steel in cracked-concrete subjected to different loading conditions", Cement and Concrete Research, 2009, 39: 116125.

[6]. Venkatesan, P., Palaniswamy, N., Rajagopal K. "Corrosion performance of coated reinforcing bars embedded in concrete and exposed to natural marine environment", Progress in Organic Coatings, 2006, 56(1):1, 8-12.

[7]. Ramniceanu, A., Weyers, R.E., Riffle, J.S. (2008), "Parameters governing corrosion protection efficacy of fusion-bonded epoxy coatings on reinforcing bar", ACI Mater. J., 2008, Vol. 105, No. 5, 459-67.

[8]. Geetha, A., Perumal, P. "Chemical Reaction of Waterproofing Admixtures on the Corrosion Behaviour of Reinforced Cement Concrete", Asian Journal of Chemistry 2011, 23(11): 51455148.

[9]. Jamila, H.E, Shriria, A., Boulifb, R., Montemorc, M.F., Ferreirad, M.G.S. "Corrosion behaviour of reinforcing steel exposed to an amino alcohol based corrosion inhibitor", Cement and Concrete Composites, 2005, 27(6): 671-678.

[10]. Ding, L., Poursaee, A. "The impact of sandblasting as a surface modification method on the corrosion behavior of steels in simulated concrete pore solution", Construction and Bulding Materials, 2017, 157: 591-599.

[11]. Angst, U.M., Elsener, B., Larsen, C.K., Vennesland, Ø. "Chlorideinduced reinforcement corrosion: electro chemical monitoring of initiation stage and chloride threshold values", Corrosion Science, 2011, 53: 1451-1464.

[12]. Song, D., Ma, A., Sun, W., Jiang, J., Jiang, J., Yang, D., Guo, G. "Improved corrosion resistance in simulated concrete pore solution of surface nanocrystallized rebar fabricated by wire-brushing", Corrosion Science, 2014, 82: 437-441.

[13]. Tang, F., Chen, G., Brow, R.K., Volz, J.S., Koenigstein, M.L. "Corrosion resistance and mechanism of steel rebar coated with three types of enamel", Corrosion Science, 2012, 59: 157-168.

[14]. Varalakshmi, R., Ramaswamy, S.N. "Effect of Anti Corrosive Coatings to Steel- A State of Art Report," International Journal of Scientific Research, 2016, 5(6):302-306.

[15]. Gunes, I., Çelik A.G., "Surface Characterization of Chromized AISI 5115 Steel by Thermo Reactive Diffusion Method" Journal of Characterization, 2021, 1(2): 61-65.

[16]. Seneviratne, A.M.G., Sergi, G., Page, C.L. "Performance characteristics of surface coatings applied to concrete for control of reinforcement corrosion", Construction and Bulding Materials, 2000, 14: 55-59. 
[17]. Gunes, I., Çelik A.G., "Surface Characterization of Borided S220 Rebar", Journal of Characterization, 2021 1(2): 66-70.

[18]. Mohmmed, J.H. "Wear Rate and Hardness of Boride Low Carbon Steel", Journal of Engineering, 2015, 10(21): 90-98.

[19]. Pertek, A., Kulka, M. (2003), “Two-step Treatment Carburizing Followed by Boriding on Medium Carbon Steel", Surface and Coatings Technology, 2003, 173: 309-314.

[20]. Erdogan, Gunes, I., (2014), Corrosion Behavior and Microstructure of Borided Tool Steel, Materia-Rio De Janeiro, 20, 523-U279.

[21]. Gunes, I, Keddam, M, Chegroune, R, M. Ozcatal. "Growth kinetics of boride layers formed on $99.0 \%$ purity nickel”, Bulletin of Materials Science, 2015, 38(4): 1113-1118.

[22]. Chegroune, R., Keddam, M., Abdellah, Z.N., Ulker, S., Taktak, S., Gunes, I., Characterization and Kinetics of Plasma-Paste-Borided AISI 316 Steel, Materiali In Tehnologije, 2016, 50: 263-268.

[23]. Suvash, C.P, Adewumi, J.B. "A Review on Reinforcement Corrosion Mechanism and Measurement Methods in Concrete", Civil Engineering Research Journal, 2018, 5(3): 555661.

[24]. Imperatore, S., Rinaldi, Z., Drago, Z. "Degradation relationships for the mechanical properties of corroded steel rebars", Construction and Building Materials, 2017, 148: 219-230.

[25]. Gunes I., Kanat, S., "Diffusion Kinetics and Characterization of Borided AISI D6 Steel", Protection of Metals and Physical Chemistry of Surfaces, 2016, 51: 842-846.

[26]. Anand, R., Rao, A.B., Manjunarh, K. "Evaluating the effect of corrosion on service life prediction of RC structures - A parametric study", International Journal of Sustainable Built Environment, 2016, 5(2): 587-603.

[27]. Krelling, A.P., Teixeira, F., Costa, C.E., Almeida, E.A.S., Zappelino, B., Milan, J.C.G. "Microabrasive wear behavior of borided steelabraded by $\mathrm{SiO}_{2}$ particles", Journal of Materials Research and Technology, 2019, 8(1): 766-776.

[28]. Gunes, I. "Wear behaviour of plasma paste boronized of AISI 8620 steel with borax and $\mathrm{B}_{2} \mathrm{O}_{3}$ paste mixtures," J Mater Sci Technol, 2013, 29: 662-668.

[29]. Ergun, Y., Gunes, I., Erdogan, M., Cankaya, N. "Effect of boriding treatment on the corrosion behavior of steels", Journal of Nanoscience and Nanotechnology, 2017, 17: 8946-8951.

[30]. Erdogan, M., Gunes, I., Dalar, A. "Investigation of corrosion behavior of borided gear steels", Transactions of the Indian Institute of Metals, 2014, 67: 291-297.

[31]. Gunes, I., Erdogan, M., Çelik, A.G. "Corrosion behavior and characterization of plasma nitrided and borided AISI M2 steel," Materials Research, 2014, 17: 612-618.

[32]. Sahin, S. "Effects of boronizing process on the surface roughness and dimensions of AISI 1020, AISI 1040 and AISI 2714," Journal of Materials Processing Technology, 2009, 209: $1736-1741$.

[33]. Zhou, H., Wang, W., Wang, K., Xu, L. "Mechanical properties deterioration of high strength steels after high temperature exposure", Construction and Building Materials, 2019, 199: 664675 .

[34]. Gunes, I., Çelik A. G., "Borlanmış Sementasyon Çeliğinin Tribolojik Özelliklerinin İncelenmesi", El-Cezeri Journal of Science and Engineering, 2019, 6: 333-344.

[35]. Gunes, I. "Investigation of Tribological Properties and Characterization of Borided AISI 420 and AISI 5120 Steels", Transactions of the Indian Institute of Metals, 2014, 67: 359-365.

[36]. Yıldız, I, Gunes, I., “\%3 Mg içeren Borlanmış Co-Mg Alaşımının Yüzey Özelliklerinin İncelenmesi”. El-Cezeri Journal of Science and Engineering, 2019, 6: 533-542.

[37]. Gunes, I., Uygunoğlu, T., Ergen, B., Kısıkçılar, T., Aksoy E., "Investigation of wear behavior of borided DIN 20MoCr4 steel", El-Cezeri Journal of Science and Engineering, 2015, 2: 5358 . 